\title{
As reverberações da história e a elaboração estética da personagem no romance Predadores
}

\section{The reverberations of history and the aesthetic elaboration of the character in Predators novel}

\author{
Jesuino Arvelino Pinto ${ }^{1}$ \\ João Batista Cardoso ${ }^{2}$
}

\begin{abstract}
Recebido em: 30/10/2020
Aprovado em: 15/12/2020

Publicado em: 20/12/2020
\end{abstract}

RESUMO: O propósito deste trabalho consiste em analisar o romance Predadores, de Pepetela, buscando apreender as formas de representação da condição itinerante que muitos grupos sociais se submetem em função das consequências de revoltas e guerras, modos de governo autoritários e mesmo de acidentes naturais. Mais especificamente, nossa proposta visa à reflexão acerca da reestruturação das memórias na formação da identidade de um povo, tendo a personagem central, Vladimiro Caposso, como elemento catalisador da trama demarcada pelo período de 1974 a 2004, compreendendo trinta anos, a partir das lutas finais pela Independência de Angola. A literatura pode servir como ferramenta de registro e manutenção dos costumes e tradições dominantes, uma vez que o discurso se materializa na oralidade e na escrita, que perpassam a História da evolução do homem como ser social. O suporte teórico deste trabalho constitui-se em estudos que permeiam a relação Literatura, História, Política e Sociedade, perpassando pelas acepções de memória e identidade, como: Mata (1993), Candido (1976, 1989), Barthes (1988), Carvalho (2010), Hall (2006), Ricoeur (2007), Lukács (2000), dentre outros. No que tange à formação da identidade cultural, a literatura traduz peculiaridades locais, manifestando os traços do momento histórico e da realidade social nela abordados.

Palavras-chave: Literatura e Vida Social; Memória; Identidade.

ABSTRACT: This paper aims at analyzing Pepetela's novel Predators, seeking to apprehend the forms of representation of the itinerant condition that many social groups submit themselves due to the consequences of revolts and wars, authoritarian modes of government and even natural accidents. More specifically, our proposal aims to reflect on the restructuring of memories in the formation of the identity of a people, having the central character, Vladimiro Caposso, as a catalyst element of the plot demarcated from 1974 to 2004, comprising thirty years, from the final struggles for Angola's Independence. The literature can serve as a tool for recording and maintaining the dominant customs and traditions, since discourse materializes itself in orality and writing, that permeate the history of the evolution of man as a social being. The theoretical support of this work consists of studies that permeate the relationship Literature, History, Politics and Society, passing through the meanings of memory and identity, such as: Mata (1993), Candido (1976, 1989), Barthes (1988), Carvalho (2010), Hall (2006), Ricoeur (2007), Lukács (2000) among others. Regarding the formation of cultural identity, the literature reflects local peculiarities, manifesting the traces of the historical moment and the social reality addressed in it.

Keywords: Literature and Social Life; Memory; Identity.

1. Graduado em Letras. Especialista em Língua Portuguesa. Mestre em Estudos Literários. Doutor em Estudos Literários pela UNEMAT, Campus de Tangará da Serra (2017). Atualmente é bolsista PNPD/CAPES, para realização do Estágio Pós Doutoramento na Universidade Federal de Goiás, Regional de Catalão. Professor Adjunto da área de Literaturas de Língua Portuguesa, na Universidade do Estado de Mato Gosso, Campus de Alto Araguaia. ORCID: 0000-0003-4900-8292 E-mail: jesuino.pinto@unemat.br 2. Graduado em Pedagogia e Letras. Mestre e Doutor em Teoria Literária e Literatura Brasileira. Docente do quadro efetivo da UFG - Regional Catalão, onde atua na graduação e no Programa de Pós-Graduação em Estudos da Linguagem. ORCID: 0000-0003-2777-6231 E-mail: jbccard@gmail.com 
PINTO, J.A.; CARDOSO, J.B.

\section{INTRODUÇÃO}

O objetivo precípuo deste texto consiste em analisar o romance Predadores, de Pepetela, buscando apreender as formas de representação da condição itinerante que muitos grupos sociais se submetem em função das consequências de revoltas e guerras, modos de governo autoritários e mesmo de acidentes naturais. Mais especificamente, nossa proposta visa à reflexão acerca da reestruturação das memórias na formação da identidade de um povo, tendo a personagem central, Vladimiro Caposso, como elemento catalisador da trama demarcada pelo período de 1974 a 2004, compreendendo trinta anos, a partir das lutas finais pela Independência de Angola.

Predadores, escrito por Pepetela em Luanda e concluído em janeiro de 2005, teve a primeira edição publicada em setembro do mesmo ano pela Editora Dom Quixote, em Lisboa. O sucesso editorial foi imediato. Em janeiro de 2006, o romance estava na $3^{\mathbf{a}}$ edição pela mesma editora. O livro é composto por vinte capítulos sem títulos, que, apesar de numerados e datados, não seguem uma cronologia, o que enriquece a estratégia narrativa. Como já indicado, a datas compreendem o período de 1974 a 2004, os trinta anos após a independência de Angola.

A trama inicia-se em 1992 com o assassinato da amante de Vladimiro Caposso e o início de romance entre Nacib e Mireille, na sequência, a história retrocede até 1974 e se detém nos anos de 1975 e 1978, contando os idos da juventude do protagonista e suas aventuras como comerciante. Depois, o enredo salta até 2004, momento em que Sebastião é designado como advogado contra a fazenda Karan, retrocedendo até 1998 para relatar as peripécias do jovem Ivan e a história de vida de sua vítima, Simão Kapiangala. Nessas idas e vindas temporais, retorna a 1997, quando enfoca Mireille e sua falta de vocação (para os negócios, até então), depois a 1985, 1991 e 1995 para mostrar a ascensão política e econômica da personagem central, saltando propositadamente até 2004, momento em que temos um princípio de derrocada de Caposso. A narrativa termina neste mesmo ano, mostrando o desfecho das personagens, ainda que não se destaquem destinos definidos. Historicamente, temos um período que vai desde o fim da guerra pela libertação, alguns meses depois da Revolução dos Cravos em Portugal, passando pela independência em 1975 e disputa de poder em Angola durante a guerra civil até chegar a 2005, três anos após seu término e quando se pode, afinal, esperar alguma constância nesse tempo de paz. 
PINTO, J.A.; CARDOSO, J.B.

\section{A (des)(re)construção da identidade de Vladimiro Caposso}

A personagem Caposso transita pelas esferas do poder em Angola nos anos de 1974 a 2004, momento das lutas finais pela Independência. O momento histórico inicial em que se insere a personagem central é uma Luanda em que os colonizadores e muitos angolanos abandonavam Angola diante da iminência de guerra entre os movimentos de libertação, ao mesmo tempo em que regressavam muitos que haviam lutado pela independência do país.

Enquanto a população se preocupava em encontrar parentes e amigos sobreviventes, os três movimentos revolucionários que lutaram pela independência do país, Movimento de Libertação de Angola (MPLA), União Nacional para a Independência Total de Angola (UNITA) e Frente Nacional de Libertação de Angola (FNLA) disputavam o poder. Vladimiro Caposso ascende lentamente econômica, política e socialmente, sempre aproveitando-se das brechas existentes no movimento político e frequentemente por meios escusos, além de saber usar da ingenuidade de algumas pessoas para explorá-las e traí-las, a exemplo de muitos outros que espertamente assim procederam e, com certeza, ainda agem. Em meio a tantos subterfúgios, corrupção e falta de ética, Vladimiro Caposso torna-se um empresário de sucesso, não sem antes inventar para si uma outra história de vida, forjando desse modo, uma nova identidade. Mas, no seio da família que constituiu ao se casar com Bebiana, revela-se um grande chefe, preocupado em provê-la, em fornecer uma educação de qualidade aos filhos, o conforto e tudo que o capital pudesse comprar. No entanto, em seu percurso, com o passar do tempo, surgem outros indivíduos tão ou mais espertos que ele, estrangeiros a quem se associou, que quase o levaram à falência. Pelo menos, enquanto sua cabeça arquitetava novos planos, só restava a ele aceitar a realidade.

Após a concretização da independência de Angola, relatada no capítulo 5, o medo de sarna de Caposso passou rapidamente: "E não percebo nada dessas políticas, nem me vou a meter. O meu pai dizia, política causa sarna" (PEPETELA, 2008, p.120). Com o MPLA no poder, interessava ao já ganancioso Caposso algumas relações com quem dominava o cenário político. Amílcar, o português de quem VC (abreviação de Vladimiro Caposso adotada pelo autor ao longo da narrativa) era funcionário, voltou para Portugal ao se sentir ameaçado pela nova situação de Angola e deixou sua loja para Caposso, ainda que não de forma definitiva nem oficialmente. A personagem, para evitar que invadissem sua propriedade, levantou um muro: "Dias depois, com as obras concluídas, escreveu nas chapas como muitos outros tinham feito na parede exterior das casas e 
PINTO, J.A.; CARDOSO, J.B.

quintais. Não encosta ou penetra, propriedade de camarada do MPLA" (PEPETELA, 2008, p. 131). É a conveniência moldando os ideais políticos de Vladimiro Caposso, que se filia ao MPLA para atingir seus objetivos, mesmo tendo de mudar seu nome e inventar/criar uma história de vida e antepassados para fazer-se confiável:

[...] Deu então os dados que o outro pedia para preencher uma ficha e o respectivo cartão.

- Nome?

- Vladimiro Caposso.

- Vladimiro?

- Como o Lenine. O meu pai era um revolucionário há muitos anos.

- E a administração colonial aceitou? Era nome proibido.

- Por isso nunca fui registrado. Vivi na clandestinidade.

O outro escreveu laboriosamente, impressionado. Escrevia muito devagar, não sendo fácil descobrir se por ser quase analfabeto ou por perfeccionismo gráfico.

- Naturalidade?

- Catete.

O funcionário escreveu mas levantou os olhos para ele. Caposso não saberia dizer se os olhos do outro denotavam admiração, respeito ou ressentimento, ainda não tinha treinado esses dons de adivinhar nas caras os sentimentos.

- Profissão?

- Empregado comercial.

Tinha já percebido, era inconveniente declarar ser dono de loja, mas também não dava dizer sou operário, devia se notar não tinha aspecto e talvez fosse preciso justificar mais tarde com papelada que nunca conseguiria. [...]

$[\ldots]$

Caposso passou no dia seguinte e de facto estava pronto o abençoado cartão que poderia lhe abrir muitas portas, com um nome que metia respeito e uma terra de origem de onde vinha gente famosa, sempre pronta a dar ajuda a um parente, pois era voz corrente, todos os catetenses eram parentes e muito unidos. (PEPETELA, 2008, p. 134-136).

Inicia-se, assim, um longo período de falcatruas, corrupção, politicagem e de dissimulação de VC, que, para a sua ascensão política, adota novo nome, altera sua cidade de origem e cria antepassados revolucionários. Os próximos capítulos confirmam esse dado, pois, nos primeiros anos pós-independência, Vladimiro conhece aquela que seria sua esposa, a inexpressiva Bebiana. Logo a engravida, casa-se com ela após reforçar o comércio de Amílcar, que já havia fechado e se transformado em sua casa, trabalha como motorista e, apenas cinco anos depois de sua filiação ao MPLA, já possui um carro próprio, um cargo de prestígio na Secretaria de Estado dos Desportos e torna-se membro do Comitê Central do Jota. A ascensão profissional do protagonista, portanto, relaciona-se direta e intimamente com o partido político dominante, aquele mesmo que Caposso antes faria de tudo para evitar qualquer contato. No entanto, o MPLA que VC evitava era aquele revolucionário e radical, bem diferente das atitudes desse novo MPLA, 
PINTO, J.A.; CARDOSO, J.B.

que estava no poder e com o qual ele identifica-se. Pepetela evidencia, na narrativa, como ocorre essa mudança na política do país, ou seja, os vitoriosos sempre herdam a estrutura e o funcionamento do sistema anterior.

É importante ter em mente que identidade cultural é, em primeiro lugar, uma manifestação do período histórico de um povo. A formação histórica, além de relevância para a formação de uma nação, também influi diretamente na produção artística, científica e literária de um povo. Nesse sentido, Carvalho (2010) enfatiza que a identidade se configurará, pois, por intermédio da identificação com os sistemas de representações simbólicas e dos sentidos construídos pelo discurso, representados no discurso, com os quais os sujeitos se identificam. A formação nacional está inteiramente relacionada à linguagem e à história, tanto na perspectiva de passado e futuro quanto na produção simbólica, ou seja, a produção cultural que dá o sentimento de pertencimento e unidade a uma coletividade.

Percebe-se que Vladimiro Caposso soube adequar-se à pirâmide do poder constituída na Angola pós-independente, pois, enquanto trabalhava como motorista, soube tirar proveito do sistema a seu favor, investindo em particulares em seu horário de expediente regular e complementando seu salário. Agora, construía sua fortuna a partir das brechas do Estado, que o favoreciam: "Na secretaria do Estado foi tendo uma carreira burocrática no gabinete de Intercâmbio, por proposta de um kamba mais antigo na Jota que tinha ocupado o cargo de director" (PEPETELA, 2008, p. 315). Assim, a personagem começa a usufruir plenamente do sistema, já que sua função lhe permitia numerosas viagens ao exterior, além de receber ajuda de custo que lhe servia para comprar presentes para a família ou mesmo para economizar em uma conta bancária.

Como parte da conduta antiética, caberá a Caposso, a pedido dos poderosos do partido, delatar um camarada por algo que ele não fez, mas apenas ser alguém que começava a incomodar seus superiores por atitudes de corrupção no partido. Ou seja, alguém que tentava resgatar os ideais do antigo MPLA, que foram abandonados por aqueles que assumiram o governo:

- Lá em cima precisam se livrar desse antigo camarada, hoje um traidor, nossa vergonha nacional. Um traidor entre vários outros, mas certamente o mais perigoso. Infelizmente ainda não se reuniram as provas suficientes para haver um processo criminal. Sabe, é complicado arranjar provas para essas coisas. E os processos criminais de dirigentes são complicados, não caem bem junto ao povo, fazem supor maquinações, sabe como é. Mas torna-se urgentíssimo retirar-Ihe pelo menos força política, para the amarrar as mãos, ele tem informações militares de grande importância, a qualquer momento pode passá-las para o inimigo, ou fazer coisa pior. Não há tempo para mais. O primeiro passo é retirá-lo do comité central. Depois,

Revista do SELL, Uberaba/MG (online) - V. 9 n. 2, p. 402-418, jul./dez. - 2020. 
PINTO, J.A.; CARDOSO, J.B.

com ele enfraquecido por já não pertencer à direcção, é muito mais fácil fazer investigações profundas e descobrir todas as provas necessárias. Temos de reforçar a disciplina interna, limpar o partido das ervas daninhas, há um grupo de traidores que põem em perigo a própria sobrevivência do partido e mesmo a unidade da nação. Compreende a urgência? (PEPETELA, 2008, p. 326-327).

No entanto, apesar de ceder aos interesses do partido, um predador maior que Caposso irá intervir, acabando com suas pretensões de ascensão rápida. Esse confronto de poderes e de interesses faz parte do processo de nacionalização de Angola pósindependência:

- Eu cumpri a minha parte. Arrisquei consequências pessoais porque confiei em si. Afinal o camarada não cumpriu sua parte no acordo.

$[\ldots]$

- Já the expliquei o que passou. Fique calmo, espere cinco anos que chega ao comité central. Mesmo estando metido até o pescoço no processo de candongueiro. Ou julga que não sabemos? Fechamos apenas os olhos. Enquanto nos for fiel e de boca calada. (PEPETELA, 2008, p. 331-332).

O fragmento nos remete às observações de Candido (1989) ao considerar que a literatura é um "sistema de produtos que são também instrumentos de comunicação entre os homens, possuem tantas ligações com a vida social, que vale a pena estudar a correspondência e a interação entre ambas." (CANDIDO, 1989, p. 162). Essa interação é o que aponta para a possibilidade de a literatura propiciar o conhecimento histórico de certa realidade por meio de um documento cultural que não pretende reduzir sua leitura a uma possível objetividade precisa e indiscutível, mas que propicia o diálogo entre as áreas de conhecimento.

\section{Literatura, História e Sociedade: reverberações}

O texto, antes de qualquer coisa, é produto da linguagem. Nasce do trabalho humano em sociedade e é testemunho material não apenas do esforço de criação individual, mas também dos condicionamentos sociais, das dimensões culturais, das condições econômicas, dos conflitos éticos e das contradições políticas, que configuram o espaço e o tempo em que foi gerado e publicado.

Inocência Mata (1993) observa que, em uma sociedade ainda carente de reflexão e de instituições que a possam impulsionar sem interesses particulares de determinados grupos, como a angolana, a literatura torna-se relevante e exerce grande influência ao "desempenhar um papel que vai além da sua significação estética e simbólica" ao evidenciar a "significação extratextual". A obra literária pode ser interpretada como a conjugação de uma memória individual sobre um passado histórico supostamente 
PINTO, J.A.; CARDOSO, J.B.

coletivo. Na produção literária de Pepetela, as contradições vivenciadas pela sociedade angolana são desnudadas nas narrativas.

Octávio Paz, em O Arco e a Lira (1982, p. 227), avalia a necessidade de pensar em conjunto História e Literatura ao afirmar que "A História é o lugar de encarnação da palavra poética". História e Literatura não devem ser vistas apenas como duas realidades paralelas, dissociadas, mas, antes, como realidades que se interpenetram por meio da escrita. Toda criação artística é produto de um tempo e de um lugar específicos, e corresponde a uma determinada atuação do homem em interação com o seu universo.

Com o objetivo de demonstrar o movimento dialético entre a arte e a sociedade num sistema de correlações e influências recíprocas, Candido (1976, p. 25-26) atribui à literatura a condição de ser fruto da iniciativa individual e de condições sociais, "na verdade ela surge na confluência de ambas, indissoluvelmente ligadas". O artista orienta sua produção segundo os padrões da época e retira das realizações humanas seus temas. A obra, por sua vez, "depende estritamente do artista e das condições sociais que determinam a sua posição" (CANDIDO, 1976, p. 30).

A obra traz, portanto, no seu interior, no conteúdo e na forma, valores sociais, incluindo-se ideologias e modalidades de comunicação, aos quais se submete o escritor. Finalmente, o público, o concretizador da obra, condicionado também por forças sociais, tem o poder de atribuir sentido a ela e definir seu valor estético. Assim, a leitura e a compreensão de um romance demandam que se desentranhe da teia de signos indícios de complexas relações entre o Homem e a Sociedade.

Considerando que as instâncias da História e da Literatura estejam dialeticamente integradas, acentuando a possibilidade de assimilação pela obra literária do contexto histórico em que ela se produziu, podemos concluir que a relação entre ficção e realidade constitui um dado inalienável ao próprio processo de criação artística. A obra é, portanto, uma configuração estética do mundo, criada pelo escritor com base num sistema simbólico de representação do real.

Além da relação entre História e Literatura, que fundamenta o conceito de representação, a mimesis aristotélica, devemos considerar a apropriação da temática histórica pela literatura como um traço recorrente na tradição romanesca. Ao lado da ficção literária que se refere diretamente a situações históricas com o objetivo primordial de criar um efeito do real, como nos ensina Barthes (1988), ou, ainda, de outras produções que situam sua intriga num determinado contexto histórico, não devemos deixar de fazer referência aos romances que tomam uma realidade qualquer do universo 
PINTO, J.A.; CARDOSO, J.B.

histórico e a transformam em sua própria matéria. Essa realidade histórica torna-se parte integrante de sua estrutura, tornando-se também uma realidade estética.

Em Predadores, assim como ocorre no conjunto de sua produção literária, Pepetela, mais uma vez, não foge ao registro dos fatos históricos. Já no primeiro capítulo, temos a marcação temporal bem delineada: "Setembro de 1992", referência histórica direta à campanha eleitoral que iria consolidar o partido do MPLA no poder. Essa referência surge já com as evidências da corrupção política: "Esta era talvez a maior concentração de veículos de sempre, na maior parte carros pertencentes ao patrimônio do Estado, buzinando estridulamente.” (PEPETELA, 2008, p. 16). Ao mesmo tempo, expõe a atitude dos que, em nome de ideologias políticas, cometem crimes e não os assumem, atribuindo-os ao partido adversário que se encontrava em desvantagem:

[...] Se atirasse as culpas para a UNITA, o partido que afrontara o governo na guerra civil e cuja violência era reconhecida até pelos próprios aderentes mais imparciais, ninguém ia investigar nada. A polícia governamental acusaria a UNITA, esta se defenderia, diria ser manobra política para a desmoralizar antes das eleições, o partido no poder, o MPLA, aproveitava imediatamente para relembrar outros crimes cometidos pelos rivais, a polêmica se instalava e ninguém ia investigar coisa nenhuma. (PEPETELA, 2008, p. 18).

Percebe-se o clima de incertezas que tomou conta do país. A trama de Pepetela expõe quantos pseudopatriotas se aproveitaram para fazer remessa de dinheiro para os paraísos fiscais e abandonar Angola com receio do resultado das urnas. Esse contexto é apresentado ao leitor sob a perspectiva de Nunes, funcionário de um banco que, com ironia, denuncia a atitude de alguns membros do poder, frente aos novos rumos políticos:

[...] - Acabo de me despedir do ministro Gonçalves que arranjou uma providencial consulta médica urgentíssima em Londres, teme-se uma doença grave, claro... E o general Arlindo já partiu para Paris, também tratar umas enxaquecas horríveis que não o deixam pensar a sério na reorganização das novas Forças Armadas. E o Andrade, e o Fontes... uma boa parte do governo já está fora. (PEPETELA, 2008, p. 33-34).

Alguns momentos e fatos, que precederam o ano da independência, são descritos no romance, como o movimento das pessoas na Rua da Delegação: "Com a vinda dos guerrilheiros que tinham combatido pela independência e a instalação de sua representação ali” (PEPETELA, 2008, p. 95). Muitos vinham saber notícias dos parentes que haviam lutado e os mais espertos vinham em busca de se infiltrarem na casa para, mais tarde, adquirirem alguma vantagem. Havia, no entanto, os bem intencionados que queriam se alistar, já prevendo as lutas internas dos partidos na disputa pelo poder. Interessante notar que, para atribuir maior verossimilhança aos fatos narrados, Pepetela 
PINTO, J.A.; CARDOSO, J.B.

menciona o poeta Lúcio Lara, um dos líderes do movimento de independência de Angola, que se envolveu muito jovem nas movimentações nacionalistas angolanas em curso desde 1950 e entre os angolanos exilados. Lara foi eleito Secretário da Organização e dos Quadros na primeira conferência nacional do MPLA, em dezembro de 1962, passando mais tarde à Secretário Geral, sendo fundamental na efetivação da independência ao lado de Agostinho Neto.

Quando o narrador faz um breve retrospecto da ação de Simão Kapiangala como soldado, destaca sua participação no combate aos sul-africanos, "racistas do apartheid", para trazer à tona "o acordo de Lusaka assinado em 1994, um dos muitos tratados que pretendiam acabar com a guerra civil." (PEPETELA, 2008, p. 229). Outro ano referenciado, mesmo que superficialmente, é 1997, como o ano em que se presumiu uma nova guerra civil.

Para Lukács (2000), o romance é o palco para exposição do confronto entre herói problemático ou satânico e o mundo, pois se trata de um gênero representativo da sociedade burguesa. Segundo o estudioso, para que se estabeleça a relação entre o social e a forma romanesca, é preciso que o escritor tenha uma visão da complexidade do mundo. Somente o escritor que percebe o mundo em sua contraditoriedade mutável será capaz de criar uma personagem em cujo destino se cruzem os contrários, as tensões e os conflitos existenciais, pois "quanto mais uma concepção do mundo é profunda, diferenciada, nutrida de experiências concretas, tanto mais plurifacetada pode se tornar a sua expressão compositiva". (LUKÁCS, 2000, p. 83).

Ainda segundo o estudioso, a evolução literária está relacionada à evolução social e ao momento de uma dialética histórico-filosófica, pois são os dados histórico-filosóficos que impõem a criação do romance, e não as intenções íntimas do escritor. Assim, a forma romanesca está conectada a cada fase da história do social porque aspira à totalidade da vida, embora pertença a um tempo em que a imanência do sentido da vida se tornou problemática, que é o tempo da sociedade burguesa. Assim, o romance como gênero é definido como um fenômeno literário próprio dessa sociedade.

Predadores é um romance de tese, tipologia agraciada pela estética realista, uma vez que sua narrativa se torna essencial para desnudar e criticar as instituições burguesas: igreja, casamento e família. Um romance que se pretenda de tese apresenta um objetivo precípuo, um propósito nítido do autor, que direciona as ações das personagens sempre visando a este fim. Assim, o autor elabora e defende uma ideia em forma de ficção. Nesse tipo de narrativa a presença de personagens redondas ou 
PINTO, J.A.; CARDOSO, J.B.

esféricas é reduzida, em sua maioria, são planas, mas sobram intenções do autor. A simplicidade, linearidade e trivialidade revelam a proposta do autor. Temos, assim, um círculo social formado por um corrupto sem escrúpulos, uma esposa submissa, um idealista desiludido, um menino honesto e esforçado, uma menina mimada, assim por diante. Segundo Foster (2004), a elaboração de personagens planas

Consiste, devo dizer, na incapacidade de perceber as profundezas e complexidades da mente humana comum; seleciona para fins literários duas ou três facetas de um homem e de uma mulher, geralmente os ingredientes mais espetaculares e portanto mais "úteis" dentre as suas características, e despreza os demais (FORSTER, 2004, p. 94).

Pepetela não intenciona, com a narrativa Predadores, expor questões comportamentais das pessoas após a independência, suas contradições ou temores. O propósito é mostrar uma Angola distópica, desencantada aos olhos de quem lutou pela revolução, extorquida e corrompida por quem a devia incentivar, além de desinteressante para a nova geração.

O narrador desse romance merece uma atenção especial. Apesar da narrativa apresentar-se em terceira pessoa, caracterizada com onisciência e onipresença, o narrador manifesta-se de forma intrusa e explícita, entre colchetes e em itálico, justificando, explicando ou mesmo provocando o leitor:

[Qualquer leitor habituado a ler mais que um livro por década pensou neste momento, pronto, lá vamos ter um flashback para nos explicar de onde vem este Vladimiro Caposso e como chegou ao que é hoje. Desenganemse, haverá explicações, que remédio, mas não agora, ainda tenho fôlego para mais umas páginas sem voltar atrás na estória, a tentar a História. $E$ desde já previno, este não é um livro policial, embora trate de uns tantos filhos da puta. Mas previno que haverá muita mistura de tempos, não nos ficaremos por este ano de 1992, em que houve as primeiras eleições, iremos atrás e iremos à frente, mas só quando me apetecer e não quando os leitores supuserem, pois democracias dessas de dar a palavra ao leitor já fizeram muita gente ir parar ao inferno e muito livro para o cesto de lixo] (PEPETELA, 2008, p. 21-22, grifos do autor).

A provocação ao leitor chega aos insultos, chamando-os de parvos (PEPETELA, 2008, p. 276), curiosos (PEPETELA, 2008, p. 383), preguiçosos, desatentos ou desmemoriados (PEPETELA, 2008, p. 432) e o narrador vai construindo sua trama, mostrando-se pouco suscetível às críticas e aos apelos dos narratários:

Pois é, por ser exagerado demais é que ponho esta coincidência aqui, adoro inverossimilhanças, impossibilidades, arriscar ser chamado de excessivo, incapaz de medir consequências e mesmo, o pior de tudo num escritor, desleixado...Nem imaginam como me reconfortam as vossas críticas e maledicências... (PEPETELA, 2008, p. 276, grifos do autor). 
PINTO, J.A.; CARDOSO, J.B.

[Por isso e eventualmente só por isso, podemos voltar a encontrar o inspector, estas estórias gostam sempre de dar muitas voltas, mas não estou prometendo nada]. (PEPETELA, 2008, p. 244, grifos do autor).

Assim, mesmo alegando que não tece juízo de valor - "Reforçaria mas não o faço, pois o autor deve ser neutro nos conflitos que as suas personagens criam" (PEPETELA, 2008, p. 480) -, o narrador demonstra, em seus comentários, exatamente o contrário, ao adotar a ironia e proferir um discurso ácido e rancoroso: "Caposso nunca leu Sartre, até pode pensar que é alguma marca de água mineral' (PEPETELA, 2008, p. 490, grifos do autor). Esse narrador tem outra estratégia que o diferencia dos demais criados por Pepetela porque é quem encerra o capítulo deixando um elo para o próximo.

As personagens são reverberações de Angola no que tange tanto à ingenuidade quanto à inconsequência. Dessa forma, a família Caposso corresponde à face daqueles que nunca vivenciaram uma revolução. Pepetela nos apresenta uma geração alienada e fútil, uma nação angolana ingênua e vulnerável que desconhece sua História, representada em personagens como Djamila, Kasseke, Manuel e Nacib. A leviandade e a inconsequência são representadas em Mireille e Ivan; o desencanto de um país que esqueceu dos seus filhos mais aguerridos em Sebastião Lopes e Simão Kapiangala; e a ambição e a corrupção em Vladimiro Caposso e seus poderosos e interesseiros aliados.

Acerca da (de)formação, construção, reconstrução e delineamento da identidade, Hall (2006) assevera que as manifestações culturais de tradições e costumes representados na literatura pós-moderna são formadas pela tríade literatura, sociedade e identidade cultural. Essa tríade é abordada pelo viés da Literatura Comparada que permite situar o período sócio histórico da nação em que a obra se insere, o contexto político e econômico da época em que a narrativa foi desenvolvida, além das concepções histórico-culturais que integram não apenas a problemática abordada, mas toda uma ideologia inerente à estética proposta pelo autor. Nesse sentido, a literatura, muitas vezes, atua como base da sociedade na qual aquele projeto artístico foi concebido. Já o registro de manutenção cultural se constrói e se reconstrói no interior das trocas sociais, na correlação ou na contraposição com outras práticas culturais.

Como o romance já indica em seu título, os predadores se apossaram da utopia, dos sonhos, das possibilidades de ascensão social das gerações que idealizaram a independência e lutaram por ela. Ainda que apresente personagens de conduta ética, como Kasseke, Manuel e Nacib, eles aparecem desprovidos de condições econômicas ou qualquer poder e engajamento necessários para se opor ao sistema corrupto e opressor que domina o país após a independência. De alguma forma e intensidade, essas 
PINTO, J.A.; CARDOSO, J.B.

personagens sofreram a problemática cultural africana que marcaram e definiram suas vidas. A identidade mítica, primitiva e tradicional atingiu Kasseke e Manuel de maneira irreversível, enquanto a atual, dividida, estratificada e transplantada, atingiu Nacib.

Essas personagens aparecem na narrativa descritas como ingênuas, tolas e crianças suscetíveis. O primeiro, Kasseke, é castrado por seu próprio pai ao tentar realizar a circuncisão, preservando uma tradição familiar daquela região de Angola, entretanto, o pai de Kasseke erra na medida e o rapaz, ao invés de circuncidado, termina castrado. Já Manuel sofreu pessoalmente o preconceito por sua própria cultura ao ser acusado de feiticeiro por sua família e ameaçado, sendo obrigado a fugir e viver nas ruas até a sua morte provocada por uma doença desconhecida, quiçá uma feitiçaria:

[...] Ficavam doentes, depois diziam que era o Manuel, feiticeiro, a chamar as doenças. Quando a mãe morreu, disseram logo foi o Manuel que puxou a doença, aí ele fugiu, com medo do castigo. Podiam até lhe matar, tu sabes? (PEPETELA, 2008, p. 353).

[...] Lhe levantaram borbulhas no corpo todo, se transformaram em chagas. [...] Kasseke comprou os medicamentos com os poucos kwanzas que acumulou mas de pouco adiantou, Manuel morreu dias depois. Até hoje Kasseke não crê em causas naturais para a morte de Manuel. Acusado de feitiçaria pela própria família, Manuel deve ter sido vítima dela (PEPETELA, 2008, p. 475).

Nacib é uma demonstração bem delineada de transplantação de cultura por ser concebido como um africano de nome árabe, inspirado em um romance brasileiro, Gabriela, Cravo e Canela, de Jorge Amado, adaptado para as telenovelas e exibida em Angola. A transnacionalização da cultura fica mais evidente quando o autor descreve os procedimentos para registro dos recém-nascidos, em que eram permitidos apenas nomes de origem angolana na tentativa de manter a identidade nacional e intimidar os estrangeirismos. Para que fosse registrado, seu padrinho teve de inventar que Nacib era um herói nacional (PEPETELA, 2008, p. 44). Trabalhador, bom filho e bom estudante, Nacib sentia-se infeliz por não viver plenamente seu amor com Mireille, filha do protagonista:

Está outra vez no buraco, pensou Nga Celestina das Dores. De facto o filho mais velho cresceu sempre com aquela tristeza que Ihe consumia, foi para a faculdade, melhorou, o sorriso frequentemente nos lábios, brincando com os irmãos e os pais, era outro. Depois de algum tempo, de novo a tristeza [...].

Celestina das Dores não ousava perguntar a Kasseke qual o drama que perseguia o filho. Sabia, se tratava de mulher, só podia. Uma mulher que ele conheceu quando era muito novo e the deu e the tirou a alegria de viver. (PEPETELA, 2008, p. 473-474).

Em lado oposto, temos personagens melhor delineadas, engajadas politicamente

Revista do SELL, Uberaba/MG (online) - V. 9 n. 2, p. 402-418, jul./dez. - 2020. 
PINTO, J.A.; CARDOSO, J.B.

e dotadas de poder e força, provenientes da memória coletiva, para enfrentar os males da Angola que se instauram no período imediato à pós-independência. Referimo-nos aqui a Sebastião Lopes, advogado, ex-militante e idealizador frustrado, mas não ressentido. Observa-se na narrativa que Sebastião Lopes teria a disposição e as ferramentas necessárias para aniquilar o sistema corrupto, porém, sem o poder suficiente para agir. Assim, os agentes que podem realmente alterar o quadro da corrupção praticada pelos mais diversos predadores seriam eles próprios, ao se devorarem, provarem de seus malefícios, chegando à destruição de si mesmos.

A personagem Sebastião é descrita como um kamba (PEPETELA, 2008, p. 95) que Vladimiro Caposso conheceu na juventude, momento em que o leitor pode inferir que teria acontecido na década de 1970. Nas palavras do narrador: "um jovem puro, queria se inscrever nas Fapla, fazer treino militar, lutar pelo país." (PEPETELA, 2008, p. 98) e "não perdia a esperança de educar politicamente o amigo" (PEPETELA, 2008, p. 100). Seu pai era motivo de vergonha por ser "cipaio" fácil dos portugueses, pago para auxiliar na repressão delatando os intentos revolucionários: "O pai de Sebastião era, nas palavras do filho, um reaccionário, defendia os colonos, eles é que trouxeram a luz eléctrica, são boa gente que nos quer civilizar." (PEPETELA, 2008, p.112).

$\mathrm{Na}$ juventude, Sebastião auxilia Caposso a conseguir o primeiro emprego estável em uma loja do português Amilcar, que futuramente constituiria o primeiro bem de Vladimiro Caposso. Mas, arrependido de indicar o emprego "pequeno burguês" ao amigo, tenta dissuadi-lo da vontade de mantê-lo:

- Mas estou bem na loja. Não tem muito trabalho. Sô Amílcar não me chateia... Nem preciso de pagar renda pelo quarto, estou a comer e vestir bem...

- Pois é isso mesmo. Estás a ficar com mentalidade de pequeno-burguês. Sabes o que é PBU? A pior coisa que há.

- Doença?

- Não. Pequena Burguesia Urbana. A classe do compromisso, que pode lixar a revolução. Os operários e os camponeses é que são o motor da mudança social, contra os burgueses, grandes ou pequenos, estás a entender? Foi o Lenine que explicou isso tudo, vou te passar o texto para estudares.

- Mas tu não és nem operário nem camponês. Não vais fazer a revolução? Estás sempre a falar nela.

- Acho que sou um intelectual. Os intelectuais revolucionários são aliados dos operários e camponeses e fazem a revolução. (PEPETELA, 2008, p. 116).

Ao retornar da guerra, desgastado pelas batalhas e por ver o muro que Caposso construíra na antiga loja do Senhor Amílcar, que agora já se constituía como sua primeira propriedade, Sebastião se afasta do amigo e os caminhos de ambos se desencontram: 
PINTO, J.A.; CARDOSO, J.B.

"Por isso Sebastião, agastado, não aceitou levá-lo ao comitê do MPLA para se inscrever e aproveitou para dizer ainda não fui a casa ver a família, depois a gente se encontra, o que era uma maneira elegante de acabar a amizade [...]" (PEPETELA, 2008, p. 132). Sebastião Lopes torna-se um modesto, mas respeitado advogado, trabalhando principalmente pelas causas que considerava mais nobres e que tinham, por assim dizer, certo teor socialista em que ele nutria suas forças.

- Sim, tens razão, és um grande malandro. Vi os olhos dele, sinto agora uma grande responsabilidade em defender esta gente. $E$ quanto a isso de sucesso, meu velho, era bem bom. Meus clientes quase nunca têm dinheiro para me pagar. Às vezes levam-me um cabrito ou uma garrafa de vinho, já não é mau. Sobretudo porque estão a dar tudo o que têm. (PEPETELA, 2008, p. 196).

A principal e mais relevante causa jurídica defendida por Sebastião Lopes envolve a Fazenda Karan, principal e mais luxuosa propriedade de Caposso. Os moradores locais, pequenos sitiantes, constituídos no processo como reclamantes, tinham, inicialmente, duas razões principais: a primeira, restabelecer o corredor para passarem os bois, utilizado há gerações pelos camponeses e que teve sua circulação impedida pelo proprietário da fazenda; a segunda, desfazer a barragem do lago, que foi desviado para atender a um dos caprichos de Caposso, que era ter um lago particular para o uso de jet ski e, por isso, a seca agora assola muitas famílias. Posteriormente, após o início da tramitação do processo, foi acrescentada a terceira reclamação, que se referia a uma indenização a ser paga para compensar às famílias os prejuízos por anos de seca e de mortes de animais ocasionadas pela dificuldade em contornar os longos desvios de caminho para acessarem a água. Acionado por Bernardino Chipengula, amigo dos tempos de cadeia que criara uma ONG para atender os menos favorecidos e para contestar o que havia se tornado o MPLA, Sebastião Lopes aceita uma ação em desfavor ao ex-amigo Vladimiro Caposso, ainda que sem rancor, nem desejo de vingança, apenas imbuído por motivações sociais.

Outra personagem apresentada por Pepetela é Simão Kapiangala, ex-combatente da guerra pela independência. $O$ autor ironiza, chegando mesmo a zombar do tratamento dado aos verdadeiros heróis pelos agentes do governo instaurado na Angola pósindependente. Sua história é digna de lástima, pois durante um treino militar, ele pisou em uma mina e "entrou na escuridão maior que a noite [...]. Ficou com dois pequenos cotos de coxas e sem coto nenhum no braço, foi mesmo amputado pelo ombro" (PEPETELA, 2008, p. 231). Na sequência, o narrador nos conta as consequências: 
PINTO, J.A.; CARDOSO, J.B.

Quando deixou de estar em perigo de vida, trouxeram-no para o Hospital Militar de Luanda, na esperança de arranjar prótese para as pernas, mas outros tinham prioridades estranhas e inexplicáveis, ele foi ficando esquecido e depois também teve de sair do hospital, ocupava o lugar de algum ferido urgentemente grave. Viveu nas ruas, ia fazer mais como? Prometeram uma pensão do Estado mas ela nunca vinha, prometeram uma casa mas ele continuou na rua. (PEPETELA, 2008, p. 233-234).

A falta de respeito e consideração evidenciada na forma de tratamento dos representantes do Estado dispensado a Simão, que se configura da transmutação de herói da guerra a mutilado maltrapilho e indigente, mostra-nos a real dimensão catastrófica das batalhas pela independência de um passado que só interessa para manutenção de privilégios de poucos. Na descrição, pormenorizada de Simão, temos com nitidez a metáfora do massacre, não físico, mas emocional, que sofreram todos aqueles que acreditaram em um futuro sem opressores após a independência, já que no período de colonização este papel era desempenhado apenas pelos portugueses. Sempre haverá alguém para oprimir, como podemos constatar em todas as revoluções inicialmente anárquicas e libertárias. Liberta-se de um sistema de opressão para se aprisionar em outro, ainda que com novos contornos e faces mais conhecidas, lembrando Foucault (1989, p. 175): “O poder é essencialmente repressivo". Usando a máscara do sentimento nacionalista de libertação de Angola, os partidos políticos, em especial o MPLA, revelaram-se novos opressores quando se dispuseram do poder.

A utopia do desenvolvimento e a corrupção de uma sociedade justa e igualitária passa a maltratar seus heróis e proteger seus inimigos. O destino final de Simão, que morre ao ser atropelado por Ivan Caposso quando é confundido com um cachorro, simboliza a nova e inconsequente geração aniquilando definitivamente e sem qualquer esforço os ideais defendidos pela geração anterior. Simão não podia mais ser diferenciado dos animais, havia perdido sua capacidade de locomover-se, banhar-se e de portar-se como um ser humano.

Paul Ricoeur (2007) considera que a memória aparece como uma única garantia de reconhecimento do passado, tendo como dimensão o tempo como justificação da sua verdade. A memória é o único instrumento que possuímos para garantir o passado, quer pessoal, quer coletivo. Além disso, ela serve como reconhecimento do passado e se relaciona dialeticamente com a História. As memórias são múltiplas e formam um painel que se altera, segundo a perspectiva de quem recorda. As escritas da memória centramse em registros factuais da história, operam com narrativas, com representações, construindo, então, variantes subjetivas do passado. 
PINTO, J.A.; CARDOSO, J.B.

Assim, conforme salienta Adolfo (1992), ao trabalhar a obra de Pepetela, a literatura mobiliza o apego na sua relação com a memória no sentido de determinar a constituição afetiva e cultural de um determinado povo, seja no registro, na manutenção ou na propagação de seus costumes e tradições. Sob a mesma perspectiva, Pinho (2014) acredita que há, na literatura, principalmente na europeia e na romântica colonial, a percepção da conquista e da chegada da civilização aos trópicos mesclada com as palavras "selvagem" e "conquistada". Sendo assim, há a procura de significados para modelos culturais eleitos e desejados na memória cultural e pessoal.

\section{CONSIDERAÇÕES FINAIS}

A literatura pode servir como ferramenta de registro e manutenção dos costumes e tradições, uma vez que o discurso se materializa na oralidade e na escrita, enquanto forma de registro dos costumes e tradições dominantes que perpassam a história da evolução do homem como ser social. Toda produção literária nega o dogmatismo e propõe a dinâmica, sempre de forma dialógica, não como um discurso da certeza, mas como o discurso da reflexão, no qual o homem cria seus ideários, características e sentimento de pertencimento a uma coletividade.

A produção literária de Pepetela lança um olhar crítico sobre a sociedade angolana, porém, em Predadores, com seu realismo, pela voz do narrador, o autor reconstrói essa mesma sociedade por um viés bem mais negativo e traumático. $O$ colorido que encontramos não é aliado da fantasia, aparece nas fortes cores e cenas do cotidiano, nas repartições públicas, nas famílias, no fosso que separa e distancia pobres de ricos e, principalmente, nas cenas de rua, em sua dura realidade: crianças pobres e abandonadas, prostituição, ex-combatentes que se tornaram mendigos. Enfim, esse colorido afasta-se da fantasia em tudo o que se pode avaliar da situação política e econômica de Angola. O quadro caótico é estruturado, à medida que acompanhamos a trajetória de Caposso, símbolo desse estado de coisas; de sua família e de seus comparsas e, por outro lado, na contramão da História no presente, mas afirmando os antigos e tradicionais valores dessa sociedade, a trajetória de outras personagens como Sebastião Lopes e Nacib.

Em Predadores, muito similar ao que ocorre em nossos dias, constatamos em Angola o desequilíbrio entre as duas vertentes da dimensão ética que permeiam a existência humana: a política e a moral; a política predominando sobre a ética e sobre a moral. Presenciamos a destruição, a aniquilação da utopia de um Estado ético, ao visar 
PINTO, J.A.; CARDOSO, J.B.

soluções individuais em que tirar proveito de tudo e de todos constitui-se norma para os sabidos e espertalhões, simbolizados por Vladimiro Caposso, que, pelo poder, recorre a todos os meios: astúcia, mentira, traições, subserviência.

\section{REFERÊNCIAS}

ADOLFO, Sérgio Paulo. A ficção de Pepetela e a formação da angolanidade. Tese de doutorado. FCL. Faculdade de Ciências e Letras - UNESP - Universidade Estadual Paulista - Campus de Assis. Assis-SP, 1992.

BARTHES, Roland. O efeito do real. In: BARTHES, Roland. O rumor da Língua. São Paulo: Brasiliense, 1988.

CANDIDO, Antonio. Literatura e sociedade: estudos de teoria e história literária. 5. ed. São Paulo: Editora Nacional, 1976. . Literatura e subdesenvolvimento. In: CANDIDO, Antonio. A educação pela noite e outros ensaios. 2. ed. São Paulo: Ática, 1989.

CARVALHO, Mariana Aparecida de. A identidade nacional angolana em $\mathbf{O}$ Vendedor de Passados. 2010. Disponível em: http://periodicos.pucminas.br/index.php/ cadernoscespuc/article/viewFile/7868/6890. Acesso em: 14 out. 2018.

FORSTER, E. M. Aspectos do romance. Tradução de Maria Helena Martins. Porto Alegre: Globo, 2004.

FOUCAULT, Michel. Microfísica do poder. Tradução de Roberto Machado. Rio de Janeiro: Edições Graal, 1989.

HALL, Stuart. A identidade cultural na pós-modernidade. 11. ed. Rio de Janeiro: DP\&A, 2006.

LUKÁCS, Georg. A teoria do romance. Tradução de José Marcos Mariani de Macedo. São Paulo: Duas cidades; Ed. 34, 2000.

MATA, Inocência. Ficção e história na literatura angolana: o caso de Pepetela. Lisboa: Edições Colibri, 1993.

PAZ, Octávio. O arco e a lira. Tradução de Olga Savary. Rio de Janeiro: Nova Fronteira, 1982.

PEPETELA. Predadores. Rio de Janeiro: Língua Geral, 2008.

RICOEUR, Paul. A memória, a história, o esquecimento. Campinas: Unicamp, 2007. 
PINTO, J.A.; CARDOSO, J.B.

Como citar este artigo (ABNT)

PINTO, J.A.; CARDOSO, J.B. As reverberações da história e a elaboração estética da personagem no romance Predadores. SELL, Uberaba, MG, v. X, n. X, p. XXX-XXX, 2019. Disponível em: <inserir link de acesso>. Acesso em: inserir dia, mês e ano de acesso. DOI: inserir link do DOI.

Como citar este artigo (APA)

Pinto, J.A., \& Cardoso, J.B. (2020). As reverberações da história e a elaboração estética da personagem no romance Predadores. SELL, $X(X), X X X-X X X$. Recuperado em: inserir dia, mês e ano de acesso de inserir link de acesso. DOI: inserir link do DOI. 